\title{
ORGANIZATION OF EDUCATIONAL WORK ON THE FORMATION OF VALUABLE ATTITUDE TO OWN HEALTH OF CHILDREN AGED 6-7 YEARS OF LIFE IN INTERACTION OF PRE- SCHOOL EDUCATION INSTITUTION AND PRIMARY SCHOOL
}

\author{
LARYSA PYECHKA
}

\begin{abstract}
The article highlights the results of the approbation of the method of forming the basis of valuable attitude to the health of children aged 6-7 years of life in the interaction of the institutions of preschool education and primary school. The stages of organization of experimental work are presented in the paper. The basic forms and methods of formation of the basis of valuable attitude to the own health of children 6-7 years of life are determined. The achievements of pre-school childhood with the purpose of their enrichment at the junior school age and ensuring the consistent growth of the child's personality are determined. The necessity of taking into account the principle of continuity in the work of the institution of preschool education and primary school is proved in relation to the formation of healthy lifestyle habits of children. The work with teachers, parents is analyzed in the context of the problem under investigation.
\end{abstract}

Keywords: children of the senior preschool age, first-graders, interaction, institution of preschool education, primary school, valuable attitude, health.

\section{INTRODUCTION}

When substantiating the methodology of the formation of the values of the valuable attitude to the own health of children aged 6-7 years of life, we took into account all its components: the purpose, the task; didactic principles of the educational process; component structure of the fundamentals of valuable attitude to health, their functions, pedagogical conditions, forms and methods of work with children, teachers of the institution of pre-school education and teachers of elementary school, parents; stages of implementation. The disclosure of the essential connections and relationships that exist between the state of health of a person, the level of knowledge about health, lifestyle, mood, relations with other people envisaged a method of forming the basis of valuable attitude to the own health in children 6-7 years life. Educational activity in the general system of work was a priority. Its main task is to develop of awareness of the value of health, healthy lifestyle, which contribute to the formation of active personality.

6-7 year old children's formation of life on the basics of valuable attitude to their own health was carried out in the context of a holistic pedagogical process, taking into account the various activities of children, their needs, interests, and their own experience of each child. In order to ensure continuity in 
the work of the institution of preschool education and elementary school, appropriate planning of the educational process based on implementation of the achievements of pre-school childhood with the purpose of their enrichment at the junior school age and highlighting the consistent growth of the child's personality is envisaged.

\section{ANALYSIS AND DisCUSSION}

One of the leading pedagogical conditions for the formation of valuable attitude to the personal health of children 6-7 years of life is the organization of appropriate subject-space educational environment.

Taking into account the principles of the modern educational environment, we have elaborated and equipped mobile centers for the realization of the right of the child to freely choose a type of activity, interaction with others, provided maximum psychological comfort. Pupils flexibly, variably used the space, being involved in the process of knowledge and learning, the formation of skills and abilities for a healthy lifestyle: independently initiated games, observations, experiments; there were included before self-massage; organized physical-cultural pauses with the use of necessary accessories and, upon completion of their conduct, came to a conclusion about the consequences of health-improving tasks. Given the accessibility of the didactic material, designers, the children consolidated knowledge about the structure and functioning of the human body. In the sports area, gymnasium there are conditions for active motor activity: there is a necessary equipment, equipment for sports games, exercises, climbing stairs, balls of different sizes, fit balls, massage mats and mats for the prevention of flatbed etc. The use of non-traditional inventory, natural material: pebbles, chestnuts, cones, seeds, grains allowed to maximize the level of health-saving activity, and game techniques helped to show interest, perform movements in an interesting, accessible form.

One of the most important tasks of the teacher is the "mediation" between the pupil and the environment in order to maximize the use of opportunities for the environment and the disclosure of the child's potential. The created conditions of environmental design have contributed to the formation of a valuable attitude to the own health and the preservation competence of pupils. They are determined by the clear design of the objects. Children have the opportunity to simulate and play health-related scenes using attributes, costume elements, sporting material and equipment (gymnastic sticks, ribbons, balls, cubes, etc.). In a relaxed way, children consolidated knowledge about a healthy lifestyle.

At sports grounds rationally placed the necessary equipment on the whole plane. It was convenient for children to use simulators in their own games. Classrooms at the school tried to equip all necessary materials and equipment for implementing projects of electives forming value attitude to their own health. School performances of puppet theater "Learning to be healthy", organizing exhibitions in libraries - the concepts of "healthy mind - healthy body", "Alphabet of Health" contributed to the formation of knowledge about healthy lifestyle.

In the canteens, the valeological culture of nutrition has increased: in the diet of students there appeared fresh vegetable salads, fresh and dried fruits, herbal tea, juices. The optimal color-lighting design helps to create a psychologically comfortable environment, develops the imagination and ability to creativity of children, especially in the organization of health and conservation activities. V. Bekhterev argued: "A skillfully chosen range of colors can have a more beneficial effect on the nervous system than other medicines" [1]. A single complex of color, kinesthetic modalities was created.

Consequently, the relevant subject-spatial environment is an integral part of the educational environment in the institution of preschool education and elementary school, where the purposeful, meaningful activity of the teacher is aimed at the formation of a healthy personality, the disclosure of its unique personality, creative potentials. At the first stage of the implementation of the methodology, we attached great importance to the formation of knowledge about the health of children. At the same 
time, we took into account the results of the research of teachers, scientists. Knowledge should be systematized, consistently lead the children to the formation of generalized ideas of ideological nature.

Work in this direction included assisting children in understanding the content, the social significance of health, the rules for strengthening and maintaining health, familiarizing with healthy lifestyles, the structure and functioning of the body through the conduct of conversations, techniques of unfinished sentences, drawing test "Healthy", "I am ill", samples of literary works and the formation of a system of value orientations on the basis of this knowledge; development of abilities to analyze and evaluate actions of fairy tale heroes, to distinguish motives of actions, to argue their estimations, to find adequate estimations of their solution, to express their impression of read works. At the final stage, the task was to formulate in children a differentiated system of knowledge, representations about health, be able to argue the chosen mode of health.

In accordance with the Basic component of preschool education, the "Child" program, the State Standards for Elementary Education, we have identified a list of skills and abilities that a child should learn in the course of classes. Work with children on the formation of the basis of valuable attitude to the own health was carried out in the process of a specially developed system of classes. For children of the senior preschool and junior school age, we used the same subject, but with the complication of practical tasks, theoretical material for first-graders. Different games, exercises, problem situations, creative games, etc. were offered to children.

The first lessons were aimed at forming in children ideas about human health, the possibility of its preservation and strengthening through its own efforts, the creation of positive relations in relation to the value of health, the promotion of active action to preserve it. The purpose of the exercise "Health the highest value" was to expand knowledge about health as a vital value, to discover knowledge of the rules of preservation and strengthening of health, to develop the ability to express emotions by their own motives.

In order to clarify the concept of health, the components of physical, mental and social health, it was suggested to observe the surrounding people to determine the appearance of their health, suggested to answer the question: "Why is health important?", "What should I do to be healthy?", "How does a healthy person look?", recall familiar proverbs and sayings about health and explain their significance. As a result of this conversation, they realized that health is one of the important values of human life, without which it is impossible to attain other good and to realize their own plans. Attention was focused on the fact that worrying about your own health should be preparation to an active, creative, adult life. At the same time, work on strengthening and maintaining health should be consistent, have a certain system. The instructor supplemented, clarified the answers, talked about the state of health, their influence on the mood manifestation of different feelings in order to update knowledge about health, a healthy lifestyle.

The next block of classes was aimed at familiarizing with the main components of health: personal hygiene, proper nutrition, sleep, motor activity, etc. The content of the classes included tasks that ensure active perception of the cognitive component. The children analyzed poetic texts and formulated their basic ideas. For example, in classes on their own hygiene for children of the senior preschool age they were offered to analyze the poems of G. Boyko "Healthy Bee", I. Kul's "Health is the basis of everything in the world", children of junior school - poem by Yu. Tuvima "Letter to all children on one important matter". During the work on these texts, children independently determined and formulated the basic rules of personal hygiene: it is necessary to brush the teeth in the morning and in the evening, wash your hands, face, neck, as well as after walks, games with pets, cleaning the room.

Creative tasks play an important role in shaping the fundamentals of valuable attitude towards health, knowledge about the strengthening and preservation of health. Children were invited to draw vegetables, fruits, various products that are healthy and explain their choices; to draw a picture of "How do I imagine health" with the following commentary. In the process of carrying out this task, an exhibition of children's creative works was organized, in the process of which deepened and systematized the representation of children about the ways of life, useful food, etc. Children actively offered various solutions to problem situations during the discussion of read texts, using their own life 
experience, the actions of fairy tale heroes who they were familiar with. Considerable attention, in the process of work, was given to the development of children's ability to put himself or herself in the position of another person.

Thoughtful conversations, observation, narration, application of the acquired knowledge provide emotional perception of new information about diseases of the body, methods of prevention, first aid for damage, vitamins and food products that increase efficiency methods of quenching and strengthening the body, the effect of mental state on a health condition of a person, means of formation of social health. Largely, to realize the importance of health works of folk art such as proverbs, sayings help a lot.

Among the effective forms of organizing the educational process, one can select an elective "From fairy tales to deeds". The purpose of the course is purposeful familiarization of children with the basic norms, rules of a healthy lifestyle. We tried to help children to understand the actions of fairy-tale heroes, to analyze their behavior and to help to understand the importance of good deeds for human health, to form the need to independently select the examples, to argue the way of strengthening and improving the organism.

The faculty consisted of several sections: "In the world of fairy tales", "School of health", "Values of a healthy lifestyle" (play of health situations of preservative content: reproduction of the dialogue of actors in dramatized games, dramatized games, plays, movable, folk games, in imaginary story situations, creative use of language means; use of desktop, finger theater). Given the higher level of development of junior schoolchildren, the second year of the experiment complicated the topic and added new: "We are familiar with the ethics of preservation and strengthening of health", "Feeling and reason in our behavior". Classes with specific subjects are developed for each section of the elective. The fairy-tale has a health-saving effect, most in line with the internal needs of the child, its essence, so it was chosen as the main genre of the used works.

In accordance with the above work, the discussion is aimed on solving the following tasks:

1) to contribute to the formation of the child's attitudes to the problems being discussed;

2) to pay attention to the usefulness of some actions, personal qualities of heroes and harm, the ugliness of others;

3) in order to form knowledge, skills to adequately assess actions, to assist in conducting an analogy between characters and their own.

Discussing the readings, the children differently solved the problem situations, applying their own life experience, the actions of fairy-tale heroes of well-known fairy tales. In working with children, we used the simulation game method [2, p. 17]. Considerable attention was paid to the development of the ability of being able to put himself or herself in the position of another person, to assess the situation with the eyes of the hero.

Playing in different situations required the children to find the right way out, applying in pairs to each other with good words. Children with an interest fulfilled tasks, explaining their choices, variants of behavior in one or another situation, the possible consequences of their implementation. For example, children of the senior preschool age were asked to play the following situation: "You offended your friend. Try to make peace with him". Younger schoolchildren were offered to visit the place both the abuser and the offender, and then find the most successful options for each side of the exit from this situation.

Our work was aimed at raising the attention of children, sensitive attitude to other people, fairly assessing the positive aspects. For this purpose, elder preschoolers were asked to make a story about the good deeds of their friends. For example, "Nadiika is very good and sensitive. She found a little puppy and took care of him. Sasha and Vova are very courageous, smart. Our team at sports entertains with their help becomes the winner".

Children of junior school age offered other tasks. For example, in the game "I By the Eyes of Friends" it was necessary to draw up a descriptive portrait of a child that is not among them. Mandatory condition - to name only the positive sides. Then the teacher voice the description already 
in the presence of the child. Thus, during a relaxed playing environment, children showed a conscious attitude towards others, marked the positive sides and expressed their feelings and feelings.

Pupils begin to realize that they need to appreciate the health of others. The systematic work of teachers in this direction allowed the children to learn how to compare the actions of people with the results, to distinguish their motives. In solving different situations, children are formed by the most important values.

To consolidate the emotional sphere: impressions, feelings, and attract children to various activities. Children were offered to practice with facial expressions, pantomime, to play an excerpt from a fairy tale, to reveal a story line, to show the characters of fairy tales; draw a picture for a specific theme of the class. We have encouraged children not only to pass on the individual features and properties of fairy tale heroes, but also to empathize with them. For example, drawing on the topic "Santa Claus got sick, asked for help" contributes to the formation of the basis of value attitude to their own health, caring attitude to other people, animals; the ability to respond to various life events and situations. In order to enhance feelings, during the drawing included music.

Before performing various game tasks, children were involved not only in classes, but also in the walk to understand the motives of others, finding the best ways to solve problems. As a mechanism of influence on the child, we used this method as a suggestion, thus inducing the children to certain conclusions, actions, used the statement of something like: "if you ..., then ...". With the suggestion in the mind of the child, certain optimistic formulas are rooted: "I am healthy", "I am happy".

Of course, the system of knowledge about health, healthy lifestyle, rules for strengthening and preserving health cannot be the only indicator of the formation of the basis of value attitude to health. The second stage involved the development of children's emotional and value sphere. The development of positive emotional attitudes towards others, surrounding is crucial in the formation of personality.

I. Bekh, O. Bilobrova, L. Lokhvitska and others defined the main conditions for the cultivation of the cognitive process: the formation of a positive attitude to the subject and methods of activity that provide an experience of success; creation of situations of emergence of the need for knowledge; organization of activity that contributes to the deepening of cognitive interest [3, p. 14-21; 4, p. 41-50; 5, p. 23].

The development of children's emotional response to health-improving actions contributed to the conduct of psychological and pedagogical training for the formation of a culture of relationships. Special attention was given to children who need correctional influence on the emotional sphere. In defining the work with children, they emphasized the following tasks:

1) creation in the children's community an atmosphere of benevolence, mutual assistance;

2) formation of the value of health as a leading one;

3) development of basic knowledge to adequately express their emotions, feelings about their own health and health of others;

4) awareness of the relationship of self-esteem with real achievements and estimates of authoritative adults;

5) assistance in the establishment of causal, semantic links between the events of life, their experiences, to respond adequately to different life situations, restraining negative emotions.

The work was aimed at familiarizing children with different emotions, peculiarities of their discovery, awareness for a good state of health, motivation for a healthy lifestyle.

First-graders were offered a game-quest "The Steps of Health". This is an interesting and, at the same time, an effective way for students to learn the necessary knowledge, skills and skills that motivate children to have a healthy lifestyle. The game provided the creation of favorable psychological conditions for effective interaction in the group, self-knowledge of the participants in the game. Interactive exercises, stimulated the interest of students, ensured the active involvement of all participants, contributed to the unity of the team of students. The results demonstrated that children in the game-quest mastered the ability to experience the emotional state of characters, learned knowledge 
about tempering and strengthening their own body, other people, able to withstand the difficulties and negative factors of the environment, expressed their desire to be healthy.

The theatrical circle "Carnival of fairy tales", where children staged fairy tales, was defined as an effective form of forming the foundations of valuable attitude towards the own health in children. The need to transfer the characters of the characters, the characteristics of their relationships, caused the children the greatest difficulties. Children so admired their own actions that they tried to accurately convey the essential features of fairy-tale heroes, their characteristic features of behavior.

During the organization of joint entertainments, the children tried to play the plot so that the spectators gained joy and pleasure. Because of this, children were interested not only in the fulfillment of their role, but also in their partners. During the rehearsal they gave each other instructions, advice, learned to support each other, when someone was mistaken, tried to help remedy deficiencies. Thus, fairy tales helped to understand the feelings of peers, to consider them in their behavior, they contributed to the development of empathy, and also contributed to the improvement of the child's body in a relaxed atmosphere.

Kinesiotherapy (motor activity) as a form of dance therapy also has a positive effect on the child. M. Berstein, R. Enok noted that kinesitherapy affects the general tone, motility, mood, promotes the training of the mobility of processes of the nervous system, activates the activity of the cerebral cortex $[6 ; 7]$.

The organization and carrying out of musical-rhythmic movements (games, dancing) contributed to the development of emotional response to health-improving actions. Scientists claim that physical health and mental health are interconnected. It is the living movement that materializes the movement of thought, feelings, and representations. Children through the movements demonstrated a different mood: joyful, outgoing, happy and vice versa, angry, annoyed, gloomy, thus allowing them to independently analyze the manifestation of not only their own emotions, but their peers. Teachers did not direct influence on what they saw, commented upon (if necessary) correction, helped to strengthen their feelings.

Music therapy is a method of regulating the mental state with the help of music [2, p. 23]. Properly selected music positively affects the emotional development of children, increases the overall tone of the body. Our proposed sessions of practical music therapy contributed positively to the emotional development of children.

After the sessions, the children expressed their feelings with pleasure, noticed that music gives strength, enthusiasm, creates a good mood. Musical-rhythmic movements restore vital forces, energy, awaken creativity, the ability to improvise, cultivate the natural movement that stimulates the development of expressiveness, rhythm, coordination, smoothness of the motor function of the body, and thus strengthens the child physically.

In order to develop an emotional component with children, psychological gymnastics was conducted. Meditation games were accompanied by musical accompaniment, called "Sunny", "Flowers", "Life of the Sea". For example, children stand in circles, stretching to the sun, turning to it verbally poetic text. The sun gives each child a sunny bunny, and then they independently perform motor actions with him, inventing a certain plot. The other tasks are the expression of feelings of the amount and compassion caused by bad health. Senior preschoolers were offered to imagine and demonstrate the state of the child, who cannot go on a walk with friends for a cold. Younger schoolchildren need to recreate not only the child's experiences, but also the anxiety of their parents caused by their child's illness. The result was the conclusion about the need for daily care of their own health and health of others.

At the end - they turned to the children with a question: "What is most memorized, will the knowledge be useful, when they can be used?" The third stage of the experiment envisaged the transformation of knowledge, representations of children into real behavior. N. Bibik emphasizes the necessity of transition in the training "from the process to the result in the activity measure, to have the appropriate potential for practical solution of life problems ..." [8, p. 45]. In the preschool age, the leading activity is the game, in the junior school - there is a new kind of activity - training. However, 
first-graders are not yet able to properly build relationships with peers, a teacher, to realize themselves as a student. It is worthwhile to hurry to replace the kind of activity important for preschool children at a certain age, and to take care of the amplification of the child's development, and therefore do not try to immediately teach the child for some reason deliberately.

Among the forms of organization of the educational process a circle "Step to health" was created. It provided for the purposeful familiarization of children with traditional and non-traditional methods of healing. During the circle work, we not only tried to get acquainted with different ways of improving the children, but also to help children to understand the value of health for human life, to form the need to independently carry out exercises and apply in everyday life to strengthen and improve their own organism. The main direction of clutch work is health-saving activity.

During the circle work, various mobile tasks, exercises and games of traditional and non-traditional forms of conducting, which aimed at the education of physical qualities, the development of motor skills, and emotional expression, were widely used. Such physical exercises have contributed to the formation of a value attitude to their own health. In particular, the children performed movements on fit balls, the task of game stretching, which involves the use of complexes of interrelated game situational exercises, aimed at developing the flexibility of the body, increase the mobility of joints and stretching the muscles, strengthening the spine, preventing flat foot. Positive emotions, cheerfulness are important factors in recovery. The established forms of conducting morning gymnastics are organically combined with the fitting for children of the practice of hatha yoga. Self-massage of biologically active zones of an organism, various kinds of massage; subject exercises, gymnastics after sleep with elements of correction; psychological exercises; vitamin therapy; aromatherapy; the use of dynamic and static exercises, etc. - Contributed to the strengthening, hardening of the body.

It should be noted that in the classroom lessons, in addition to new information on mobile tasks and physical exercises, there were repetitions. Thanks to the organized work, the children fixed the material, remembering it better. Accordingly, in the future children could implement them at home. Participation of children in events involves their activity, which allows you to overcome weakness, indifference, quarrel, improvement of the surrounding world.

An important means of involving children in the formation of the fundamentals of valuable attitude towards their own health was the well-thought-out cooperation of an adult with children. At the same time, we tried to encourage the child to realize himself as a subject of activity, the creator of his own ideas. To this end, children developed the ability to adequately assess their own behavior, rejoice in their own successes, implement plans in concrete actions; adjusted in the ability to verbalize feelings, impressions from their actions about a healthy way of life.

The systematic holding of preschool education and elementary school of physical culture and recreation activities: entertainment, holidays, and health days contributed to the formation of stable positive attitudes towards the environment among children, feelings of responsibility, responsibility, strengthening of the skills of observing a healthy lifestyle, the ability to empathy.

The content of the work with the pedagogical staff was aimed at raising the level of knowledge and ideas about health, awareness of the specifics of education of the health culture of children aged 6-7 years of life, the essence of continuity in the upbringing of a healthy child, deepening knowledge about the psychological, physical development of 6-7 year old children, determining the main directions of work. The experience of primary school teachers was enriched with the necessary substantiation of the means, forms, and methods of organizing the educational process aimed at preserving, strengthening and shaping the health of children, which determined their responsibility for the formation of a physically and spiritually healthy personality.

An agreement on cooperation between school and the institution of pre-school education was concluded. It included the annual plans of the chapter "Formation of the basis of value attitude to own health: continuity and perspective in the work of the institution of preschool education and school"; a list of joint activities is defined: 1) holding of joint workshops; 2) mutual learning (lessons) with the aim of sharing the accumulated pedagogical experience. 
The author created a collection of scientific and methodological recommendations "Step to health" for active use by teachers in the practice of work [9]. The recommended exercises in a rational combination with other organizational forms of health-saving activity helped create the optimal motor regime, contributed to improving the functional capabilities of the body, able to improve the working capacity of children, and contribute to the preservation of their health.

No less important direction in the system of work on the formation of the basis of valuable attitude to the health of children is cooperation with the family. Depending on the interests and wishes of the parents, the work of the teachers with the family was conducted individually, with the staff of the parents, informationally. The parents held group consultations, "round tables", trainings, general meetings, as well as lectures, conferences, consultations with the involvement of specialists; thematic exhibitions.

Information forms of work included the use of thematic folders-transcripts with a selection of practical recommendations, the placement of materials in monthly health bulletins, albums, parent corners, "corners of health", oral journals, information stands, sites; preparation of media presentations for the reporting period "The best experience of hardening in the family", "Most active", etc. Such activities have attracted the attention of parents to the behavior of their children in the complex. They have an interest in the achievements of the child in relation to her attitude to health, her possession of skills, behavior skills during the conduct of regime processes, in everyday life, in building relationships with peers, to notice problems and achievements, to find out the failures.

As the information on the formation of the basis of valuable attitude towards the own health of children 6-7 years of life, the interest of parents increased. It was expressed in increasing their activity in the work of the educational institution.

\section{CONCLUSIONS}

Thus, the results of the forming experiment allowed to make the following conclusions: effective formation of the basis of value attitude to their own health is possible under the condition of a comprehensive impact on the cognitive, emotional and value, behavioral and activity spheres of the growing person.

The effectiveness of the formation of the basis of value attitude to their own health depends on the realization of the unity of requirements in educational institutions and the family. Cooperation was focused on the formation of knowledge about them about the forms and methods of raising children in the family from the standpoint of personality-oriented approach. For this purpose, the following methods of studying the family were used: conversation, communication, their assessment, visits to families of pupils, questioning of parents, interaction with peers, etc. Depending on the interests and wishes of parents, the work of teachers with the family was conducted individually, collectively, informatively, with observance of certain principles.

\section{REFERENCES}

[1] Bekhterev V.M. Problems of Development and Education of a Person. Institute of practical psychology, Moscow; MODEC, Voronezh, 1997. (in Russian)

[2] Tarasevich N.M. (Ed.) et al. Dictionary of Terminology from Pedagogical Skill. Poltava V.G. Korolenko National Pedagogical Institute, Poltava, 1995. (in Ukrainian)

[3] Bekh I.D. Educational humanistic paradigm in educational innovation. Pedagogics and Psychology, 2 (2016), 14-21. (in Ukrainian)

[4] Bilobrova O. Educate a healthy baby. Dytiachyi Sadok, 22 (2012), 41. (in Ukrainian) 
[5] Lokhvytska L.V. Formation of cognitive interests of children of the senior preschool age in educationalgame environment. Dissertation for the degree of Candidate of Pedagogical Sciences: 13.00.08. Kyiv, 2000. (in Ukrainian)

[6] Josef M. Feigenberg. Nikolai Bernstein: From Reflex to the Model of the Future. In: Wolfram P. (Ed.) et al. Studien zur Geschichte des Sports, 17. LIT Verlag, Münster, 2014.

[7] Enoka R.M. Basics of Kinesiology. Olympic literature, Kyiv, 2000. (in Ukrainian)

[8] Ovcharuk O.V. (Ed.) Competency Approach in Modern Education: World Experience and Ukrainian Perspectives. Library of Educational Policy. KIS, Kyiv, 2004. (in Ukrainian)

[9] Piechka L.E. Modern Preschool Education. Step to Health. Kremenchug Pedagogical College named after A. S. Makarenko, Kremenchug, 2008. (in Ukrainian)

Address: Larysa Pyechka, M. P. Dragomanov Kyiv University, 9, Pirogova Str., Kyiv, 01601, Ukraine.

E-mail: lara_ppp@ukr.net

Received: 04.01.2019; revised: 20.03.2019.

Печка Лариса. Організація освітньої роботи щодо формування основ ціннісного ставлення до власного здоров'я дітей 6-7 року життя у взаємодії закдаду дошкільної освіти і початкової шкоди. Журнал Прикарпатського університету імені Василя Стефаника, 6 (1) (2019), 133-141.

У статті висвітлено результати апробації методики формування основ ціннісного ставлення до власного здоров'я дітей 6-7 року життя у взаємодії закладу дошкільної освіти і початкової шкоди. Представлено етапи організації експериментальної роботи. Визначено основні форми і методи формування основ ціннісного ставлення до власного здоров'я дітей 6-7 року життя. Визначено здобутки дошкільного дитинства задля їх збагачення в молодшому шкільному віці й забезпеченні послідовного зростання дитячої особистості. Доведено необхідність врахування принципу наступності у роботі закладу дошкільної освіти та початкової шкоди щодо формування у дітей навичок здорового способу життя. Проаналізовано роботу з педагогами та батьками в контексті практичного вирішення досліджуваної проблеми.

Кдючові слова: діти старшого дошкільного віку, першокласники, взаємодія, заклад дошкільної освіти, початкова школа, ціннісне ставлення, власне здоров'я. 